Archives of Agriculture and Environmental Science

\title{
A comparative study on morphology, mineral and vitamin compositions of two variants of Hibiscus sabdariffa (L.)
}

\author{
C.V. Ilodibia ${ }^{1^{*}}$ (D) , U.A. Achebe ${ }^{2}$, C.U. Arubalueze ${ }^{2}$ and E. Ibeh ${ }^{1}$ \\ ${ }^{1}$ Department of Botany, Nnamdi Azikiwe University, P.M.B 5025, Awka, Anambra State, NIGERIA \\ ${ }^{2}$ Department of Agricultural Education, Nwafor Orizu College of Education Nsugbe, Anambra State, NIGERIA \\ *Corresponding author's E-mail: chinyereokafor206@yahoo.com
}

\section{ARTICLE HISTORY}

Received: 07 February 2019

Revised received: 11 February 2019

Accepted: 25 February 2019

\section{Keywords}

Comparative

Food and drug supplements

Hibiscus sabdariffa

Mineral

Morphological

Vitamins

\section{ABSTRACT}

Morphological, mineral and vitamin compositions of leaves and seeds of two varieties of Hibiscus sabdariffa L. were evaluated using standard techniques and compared. Analysis of variance was employed in data analyses. Morphological study showed no significant difference in their habit, structure and phyllotaxy but varied mostly in sizes and colour. The red variety had a greater leaf area $\left(94.25 \pm 0.310 \mathrm{~cm}^{2}\right)$ and petiole length $(6.50 \pm 0.620 \mathrm{~cm})$ than the green variety, whose leaf area and petiole length are $53.95 \pm 0.400 \mathrm{~cm}^{2}$ and $3.60 \pm 0.332 \mathrm{~cm}$ respectively. The minerals and vitamins were found to be present in all the parts of the two varieties investigated but in varying levels. Higher composition of the minerals and vitamins were found in the leaves than the seed. However, the nutrients were higher in the red variety. The results of the study revealed that these parts of the two varieties investigated are nutritious and can contribute significantly to the human health requirements thus could be extracted for the manufacture of food and drugs supplements. Overall data could be used as a viable tool in Roselle breeding for improvement in Roselle production and also to enhance proper taxonomic characterization and identification of the plant species which have immense economic potentials as ornamental plants.

(C)2019 Agriculture and Environmental Science Academy

Citation of this article: Ilodibia, C.V., Achebe, U.A., Arubalueze, C.U. and Ibeh, E. (2019). A comparative study on morphology, mineral and vitamin compositions of two variants of Hibiscus sabdariffa (L.). Archives of Agriculture and Environmental Science, 4(1): 50-56, https://dx.doi.org/10.26832/24566632.2019.040108

\section{INTRODUCTION}

Roselle (Hibiscus sabdariffa L.) belongs to the family Malvaceae, which consists of plants whose fruits are capsule, schizocarps or nuts (Judd et al., 2008; Mukherjee et al., 2017). The family consists of 243 genera and Hibiscus is among the largest genera in terms of number of species (Judd et al., 2008; Mohamed et al., 2012). The species of this genus (Hibiscus) are often noted for their showy flowers and are commonly known as hibiscus or rose mallow (Lawton, 2004; Mokhtari et al., 2018). The plant is widely grown in the Tropic including Caribbean, Central America, India, Africa, Brazil, Australia, Hawaii, Florida and Philippine, as a home garden crop (Mahadevan et al., 2009).

The species $H$. Sabdariffa comprises a large number of cultivated types which, based on their growth, habit or end use, are classified broadly under two varieties, H. Sabdariffa var. sabdariffa and H. Sabdariffa var. altissima Wester (Gautam, 2004). Several cultivars and varieties of Hibiscus sabdariffa are known (Orwa et al., 2009). In Nigeria the two most common botanical varieties are the green and red. The red variety is shorter and bushy in form; it has red or pale yellow inflated edible calyces, but poor fiber; while the green variety is erect, sparselybranched annual and grows up to $16 \mathrm{ft}(4.8 \mathrm{~m})$ high (Morton, 1987; Da-Costa-Rocha et al., 2014). Roselle is usually propagated by seed but grows readily from cuttings (Morton, 1987; Judd et al., 2008). It succeeds best in tropical and Subtropical regions. Deep, fairly fertile sandy loam soil is preferable to grown roselle (Morton, 1987; Mwasiagi et al., 2014). It is grown for its fiber, but has inedible calyces (Morton, 1987; Orwa et al., 2009; Abdallah, 2016). The calyx of the red variety is used for the preparation of "Zobo" drink and soup, and the calyx of the green variety is used to cook soup, stew and sauces (Babalola, 2000). 
The calyx of roselle (green) is very rich in vitamin $C$ and riboflavin with some major mineral present (Babalola, 2000). The green variety is more predominant in the Southern part of Nigeria, although is scarce. The red varieties are predominant in the Northern part. The calyces of these varieties have a number of uses and promising prospects for industrial purposes (Alegbejo, 2000; Daudu et al., 2015).

Roselle may have exploitable possibilities as a natural food product and as a colourant to replace some synthetic dye (Morton, 1987; Mohamed et al., 2007). In China, it is used to treat hypertension, pyrexia, and liver damage (Tsai and Ou, 1996; El Hakim, 2010) and lately its sepal extract has been used as an effective treatment against leukemia, due to its high content in polyphenols, particularly protocatechic acid (Odigie et al., 2003). Hibiscus sabdariffa is usually taken as a drink made from the calyx, especially in the western part of Africa and has been recommended as a remedy for various ailments such as hypertension, pyrexia and liver disorders (Essa et. al., 2006; Obouayeba et al., 2014). It has also been said to be a mild diuretic and purgative, among many other effects (Essa et al., 2006). The in vivo pharmacological activities as antipyretic, antioxidant and anticholesterol products were screened in rats and rabbits (Ali et al., 2005; Ochani and D'Mello, 2009). It was also proved effective in regulating human blood pressure (Haji-Faraji and Haji-Tarkhani, 1999; Herrera-Arellano et al., 2004). In some countries, its shrubbery is used for decorative purposes, in others, the seeds and petals are used for human consumption (HerreraArellano et al., 2004). The calyces are used to produce infusions that are consumed like tea (Konan et al., 2015). The fresh calyces of roselle are rich in riboflavin, ascorbic acid, niacin, carotene, calcium and iron that are nutritionally important (Mahadevan et al., 2009; Singh et al., 2017), as well as amino acids and mineral salts (Cisse et al., 2009). Early studies reported that $H$. sabdariffa contains protein, carbohydrate, vitamin C, $\beta$-carotene and iron (Ismail et al., 2008; Singh et al., 2017).

Despite the immense importance of this species, the nutritional (mineral and vitamins) potentials of the varieties commonly consumed by our people are lacking, hence the need for the present study. Accordingly, the problem and focus of this research is to ascertain the morphological and nutritional properties of the two varieties of Hibiscus sabdariffa (green and red varieties) found in Nigeria.

\section{MATERIALS AND METHODS}

\section{Study area}

The nutrient analysis was carried out at Springboard Laboratory Awka, (6 $6^{\circ} 12 \mathrm{~N}^{\prime}, 7^{\circ} 04 \mathrm{E}^{\prime}$ ) Anambra State. Field studies were carried out in Awka. Awka is located in the tropical rain forest zone of Nigeria with average temperatures, annual rainfall and relative humidity of $29^{\circ} \mathrm{C}, 2700 \mathrm{~mm}$ and $87 \%$ respectively.

Procurement, identification and preparation of plant material The leaves and seeds of both varieties were oven dried at $65^{\circ} \mathrm{C}$ for 6 hrs. The dried leaves and seeds were crushed into fine powder for mineral and vitamin analysis. The leaves and seeds of both varieties (red and green) of Hibiscus sabdariffa were collected between March-May 2017 from a farm in Burunji, Jimeta-Yola, Adamawa State. The samples were authenticated and given voucher number by a taxonomist in the Department of Botany, Nnamdi Azikiwe University, Awka. Some of the seeds of both varieties were germinated in the field for morphological studies.

\section{Morphological studies}

Observations on vegetative characteristics were studied using samples collected from mature plant. For the leaves, the third and fourth fully opened leaves from the stem tip were used. A meter rule was used to measure the petiole length, leaf length and leaf base. The plant height and stem girth was measured using a tape rule, while the leaf texture, leaf shape, leaf margin, stem colour, leaf arrangement, leaf type, and leaf venation were studied by keen observation (This is as outlined by llodibia et al., 2017).

Mineral and vitamin studies

Mineral ( $\mathrm{Na}, \mathrm{K}, \mathrm{Ca}, \mathrm{Mg}$ and $\mathrm{P}$ ) and vitamin (Vit A, Vit $\mathrm{B}_{1}$, Vit $\mathrm{B}_{2}$, Vit $B_{3}$ and $\left.V i t C\right)$ were determined following the methods of James (1995) and AOAC (2005).

\section{Materials and reagents used}

The used materials were as electronic balance, box resistance furnace, crucible, desiccator, beakers, conical flasks, burette, spectrophotometer, flame photometer, separating funnel, Whatman no.1 filter paper, funnel, water bath, petri-dishes, masking tape, and sample bottles. The chemical used in this study were as: $\mathrm{HCl}(2 \mathrm{M})$, Potassium ferrocyanide (masking agent), Solochrome dark blue, Erichome Black T, 0.02N EDTA, Ammonia buffer, Distilled water, Phosphorus colour reagent, Absolute ethanol, $50 \% \mathrm{KOH}$, Petroleum ether, $20 \% \mathrm{KI}, 1 \%$ Starch, Copper sulphate, Alcoholic $\mathrm{NaOH}$, Potassium dichromate, $50 \%$ Ethanol, $\mathrm{KMnO}_{4}, 30 \% \mathrm{H}_{2} \mathrm{O}_{2}, 40 \% \mathrm{NaSO}_{4}$, Normal $\mathrm{H}_{2} \mathrm{SO}_{4}$, Ammonia, $0.02 \% \mathrm{H}_{2} \mathrm{SO}_{4}$, 6\% EDTA, Sodium cyanide, Sodium potassium ferrocyanide, Potassium dichromate, and Hydroxylamine hydrochloride.

\section{Statistical analysis}

Results were presented in mean \pm standard deviation and were subjected to analysis of variance (ANOVA) using Duncans Multiple Range Test (DMRT) at 5\% probability to separate the treatments. Differences in mean value were considered significant at $p<0.05$. Bar charts were used to illustrate the percentage composition of mineral and vitamin in both varieties plant part.

\section{RESULTS AND DISCUSSION}

Results of the study are presented in Tables 1 - 3 and Figures 1 - 4.

\section{Morphological studies}

Observations on the morphology of two varieties (red and green) of Hibiscus sabdariffa (Table 1 and Figures 1-3 showed 
that the red variety is a shrub and about $3.30 \pm 0.81 \mathrm{~m}$ in height; the phyllotaxy is alternate; leaves are $9.40 \pm 0.52 \mathrm{~cm}$ wide and $10.00 \pm 0.60 \mathrm{~cm}$ long; simple, smooth, reddish green in colour, have serrated margin; venation is reticulate, apices acuminate; base is rounded, leaf area is $94.25 \pm 0.31 \mathrm{~cm}^{2}$, petiole is $6.50 \pm 0.52 \mathrm{~cm}$ long. Stem is glabrous in nature, red in colour and circular in shape; $2.20 \pm 0.73 \mathrm{~cm}$ in girth. Root type is tap root; flower type is hypogynous and yellow in colour; inflorescence is solitary (axillary) placentation is axile, sepal gamosepalous and bell shaped; petals overlapping (polypetalous) and bell shaped.

The green variety is a shrub and about $3.80 \pm 0.63 \mathrm{~m}$ in height; the phyllotaxy is alternate; leaves are $6.50 \pm 0.62 \mathrm{~cm}$ wide and $8.30 .00 \pm 0.45 \mathrm{~cm}$ long; simple, smooth, greenish in colour, have serrated margin; venation is reticulate, apices acuminate; base is rounded, leaf area is $53.95 \pm 0.40 \mathrm{~cm}^{2}$, petiole is $3.60 \pm 0.33 \mathrm{~cm}$ long. Stem is glabrous in nature, red in colour and circular in shape; $1.80 \pm 0.43 \mathrm{~cm}$ in girth. Root type is tap root; flower type is hypogynous and white in colour; inflorescence is solitary (axillary) placentation is axile, sepal gamosepalous and bell shaped; petals overlapping (polypetalous) and bell shaped (Table 1 and Figures 1-3). The result revealed some similarities and differences in the morphological characteristics between the varieties. Similarities were observed in the habit, leaf type, leaf arrangement, base, texture, venation, apices, stem shape, nature, root type and flowers. Differences were observed in the plant height, colors, leaf length, width, leaf area, petiole length and stem girth. These similarities could be because they belong to the same species 'sabdariffa'. The differences could be the reason for the different varieties. Qualitative and quantitative characteristics observed strengthens the intra and interspecific relationship and can be used to enhance proper taxonomic characterization and identification of the plant species which have immense economic potentials as ornamental plants. High variability among crop genotypes based on phenotypic characters has been reported by some authors (Aremu et al., 2007; Adewale et al., 2010, Aziagba et al., 2016 and Ilodibia et al., 2018). The result is in line with the morphological descriptions of Morton (1987) and Orwa et al. (2009) except in those features they did not study respectively.

Table 1. Morphological features of the red and green varieties $H$. sabdariffa.

\begin{tabular}{|c|c|c|c|}
\hline Tissue & Parameter & Red Variety & Green Variety \\
\hline & Habit & Shrub & Shrub \\
\hline & Plant height & $3.3 \pm 0.81 \mathrm{~m}$ & $3.8 \pm 0.63 m$ \\
\hline \multirow[t]{12}{*}{ Leaf } & Leaf colour & Reddish green & Green \\
\hline & Leaf type & Simple & Simple \\
\hline & Leaf arrangement & Alternate & Alternate \\
\hline & Leaf texture & Smooth & Smooth \\
\hline & Leaf venation & Reticulate & Reticulate \\
\hline & Leaf margin & 3 to 5 lobed (serrated) & 3 lobed (serrated) \\
\hline & Leaf apex & Acuminate & Acuminate \\
\hline & Leaf base & Rounded & Rounded \\
\hline & Leaf length & $10.0 \pm 0.60 \mathrm{~cm}$ & $8.3 \pm 0.45 \mathrm{~cm}$ \\
\hline & Leaf width & $9.4 \pm 0.58 \mathrm{~cm}$ & $6.5 \pm 0.62 \mathrm{~cm}$ \\
\hline & Leaf area & $94.25 \pm 0.31 \mathrm{~cm}$ & $53.95 \pm 0.40 \mathrm{~cm}$ \\
\hline & Petiole length & $6.5 \pm 0.52 \mathrm{~cm}$ & $3.6 \pm 0.33 \mathrm{~cm}$ \\
\hline \multirow[t]{4}{*}{ Stem } & Stem colour & Red & Green \\
\hline & Stem shape & Circular & Circular \\
\hline & Stem nature & Glabrous & Glabrous \\
\hline & Stem girth & $2.2 \pm 0.73 \mathrm{~cm}$ & $1.8 \pm 0.43 \mathrm{~cm}$ \\
\hline Root & Root system & Tap root & Tap root \\
\hline \multirow[t]{8}{*}{ Flower } & Flower colour & Yellow & White \\
\hline & Inflorescence & Solitary (Axillary) & Solitary (Axillary) \\
\hline & Flower type & Hypogynous & Hypoynous \\
\hline & Placentation & Axile & Axile \\
\hline & Sepals & Gamosepalous & Gamosepalous \\
\hline & Sepal shape & Bell-shaped & Bell-shaped \\
\hline & Petals & Overlapping (polypetalous) & Overlapping (polypetalous) \\
\hline & Petal Shape & Bell-shaped & Bell-shaped \\
\hline
\end{tabular}


Table 2. Mean mineral composition of the leaf and seed of red and green varieties of Hibiscus sabdariffa (mg/100g).

\begin{tabular}{ccccc}
\hline Minerals & \multicolumn{2}{c}{ Red Variety } & \multicolumn{2}{c}{ Green Variety } \\
\hline $\mathrm{Na}$ & Leaf & Seed & Leaf & Seed \\
$\mathrm{K}$ & $46.68 \pm 0.17$ & $34.70 \pm 0.00$ & $49.69 \pm 0.04$ & $39.38 \pm 0.00$ \\
$\mathrm{Ca}$ & $84.49 \pm 0.30$ & $92.76 \pm 0.00$ & $106.26 \pm 0.17$ & $116.44 \pm 0.36$ \\
$\mathrm{Mg}$ & $110.23 \pm 0.33$ & $52.67 \pm 0.09$ & $94.45 \pm 0.20$ & $40.80 \pm 0.00$ \\
$\mathrm{P}$ & $124.85 \pm 0.01$ & $120.78 \pm 0.18$ & $132 . .50 \pm 0.00$ & $106.8 \pm 0.14$ \\
\hline
\end{tabular}

Results are as mean \pm Std error.

Table 3. Mean vitamin composition of the leaf and seed of red and green varieties of Hibiscus sabdariff.

\begin{tabular}{ccccc}
\hline Vitamins & \multicolumn{2}{c}{ Red Variety } & \multicolumn{2}{c}{ Green Variety } \\
\hline & Leaf & Seed & Leaf & Seed \\
\hline Vitamin A & $10.45 \pm 0.00$ & $8.54 \pm 0.17$ & $3.43 \pm 0.25$ & $1.18 \pm 0.00$ \\
Vitamin B1 & $1.46 \pm 0.00$ & $1.25 \pm 0.00$ & $1.20 \pm 0.00$ & $1.08 \pm 0.04$ \\
Vitamin B2 & $1.72 \pm 0.09$ & $1.46 \pm 0.00$ & $1.58 \pm 0.18$ & $1.00 \pm 0.09$ \\
Vitamin B3 & $0.90 \pm 0.00$ & $0.76 \pm 0.00$ & $7.34 \pm 0.09$ & $1.33 \pm 0.11$ \\
Vitamin C & $15.58 \pm 0.18$ & $11.60 \pm 0.00$ & & $5.98 \pm 0.11$ \\
\hline
\end{tabular}

Results are as mean \pm Std error.

Mineral and vitamin studies

The result showed that minerals were present in all the parts of $H$. sabdariffa varieties investigated but in varied levels (Table 2 and Figure 4). This indicated that these parts of $H$. sabdariffa varieties investigated are good sources of minerals assayed and could be extracted for the development of food and drug supplements. Sodium ( $\mathrm{Na}$ ), Calcium ( $\mathrm{Ca}$ ), and Magnesium (Mg) contents were higher in the leaves when compared to the seeds of the two varieties; although the minerals were higher in green than in the red variety. Sodium $(49.69 \pm 0.04)$, magnesium $(132.50 \pm 0.00)$ and $(110.23 \pm 0.33)$ calcium were found in the leaf of the green variety while $(46.68 \pm 0.17),(124.85 \pm 0.01)$ and $(94.45 \pm 0.21)$ sodium, magnesium and calcium respectively were found in the leaf of the red variety (Table 2 and Figure 4). This showed that the leaf and the green variety are a better source of the above minerals when compared to the seed and the red variety. Phosphorus and potassium were higher in the seeds of both varieties than the leaves, although phosphorus $(44.76 \pm 0.00)$ was higher in the red variety than green variety $(42.47 \pm 0.16)$ while potassium $(116.44 \pm 0.37)$ was higher in the green than the red variety $(92.76 \pm 0.00)$. This showed that the seed is a better source of the above minerals when compared to the leaf. While the red variety is a better option for phosphorus, the green variety is a better option for potassium. This essential mineral is required for the successful growth and reproduction of an organism. Phosphorus is essential for the synthesis of nucleic acids, ATP and some proteins. Also, phosphate is a constituent of bone and enamel. Potassium is mainly associated with membrane function, cofactor in photosynthesis and respiration and is common in cell sap of plant vacuoles. Sodium is similar to potassium, but usually present in lower concentrations. Magnesium is part of structure of chlorophyll, bone and tooth structure, also, cofactor for many enzymes e.g. ATPase. Calcium is necessary for the formation of middle lamella (calcium pectate) between plant cell walls and normal cell wall development. It activates ATPase during muscular contraction and helps in blood clotting (Taylor et al., 2005 and Ilodibia et al., 2016a, b and c). The result showed that vitamins were present in all the parts of $H$. sabdariffa varieties investigated but in varied levels (Table 3 and Figure 5). This indicated that these part of $\mathrm{H}$. sabdariffa varieties investigated are good sources of vitamins assayed and could be extracted for the development of food and drug supplements. The vitamins (Vit A, B1, B2, B3 and C) were higher in the leaves when compared to the seeds of both varieties, although the vitamins were higher in the red variety (both leaf and seed) than green variety except vitamin B3 that was higher in the leaf and seed of green variety. The compositions of Vit A, B1, B2, B3 and C in the leaf of the red variety were $(10.45 \pm 0.00),(1.46 \pm 0.00),(1.72 \pm 0.09),(0.90 \pm 0.00)$ and $(15.58 \pm 0.18)$ respectively. While that in the leaf of green variety were $(3.43 \pm 0.25),(1.18 \pm 0.00),(1.20 \pm 0.00),(1.58 \pm 0.18)$ and (7.34 \pm 0.08$)$ respectively. The compositions of Vit A, B1, B2, B3 and $C$ in the seed of the red variety were $(8.54 \pm 0.17)$, (1.25 \pm 0.00$),(1.46 \pm 0.00),(0.76 \pm 0.00)$ and $(11.60 \pm 0.00)$ respectively. While that in the seed of green variety were $(2.65 \pm 0.07)$, $(1.08 \pm 0.04),(1.00 \pm 0.09),(1.33 \pm 0.11)$ and $(5.98 \pm 0.11)$ respectively. This showed that the leaf is a better source of the vitamins investigated when compared to the leaf. The red variety is a better source of the vitamins except Vit.B3. Vitamins help resist infections, keep nerves healthy, and help the body get energy from food or blood to clot properly. Vitamin A is a fatsoluble vitamin while vitamins $C$ and $B$ are water -soluble vitamins. Vitamin A is an antioxidant and plays role in Vision, Bone growth, Reproduction, Cell functions and Immune system. B vitamins help the process the body uses to get or make energy from the food we eat. They also help form red blood cells. Vitamin $C$ is an antioxidant. It is important for your skin, bones, and connective tissue. It promotes healing and helps the body absorb iron (Medline plus, 2015; Davey et al., 2000 and Ilodibia et al., 2016a, b and c). The vitamin C obtained from the leaves of both varieties compared favourably with those obtained from the calyces (red and green varieties) of Roselle by (Adanlawo and Ajibade, 2006), and also with some edible mushrooms and to some of animal organs. 

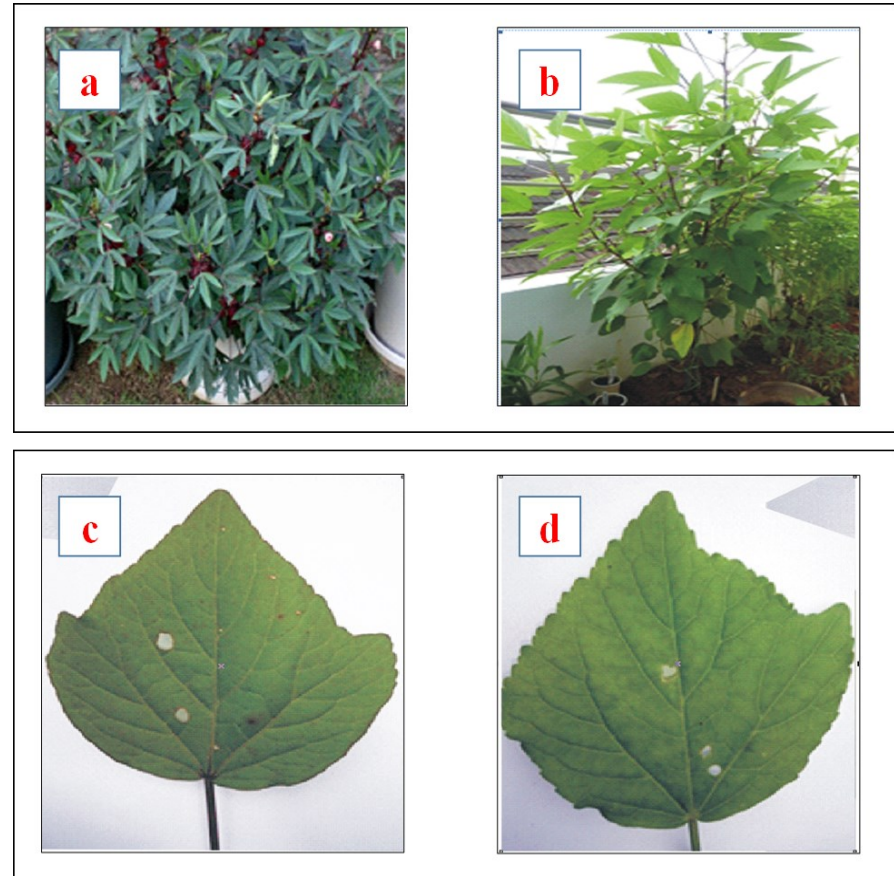

Figure 1. a) H. sabdariffa red variety; b): H. sabdariffa green variety; c): Leaf of red variety; d): Leaf of green variety.
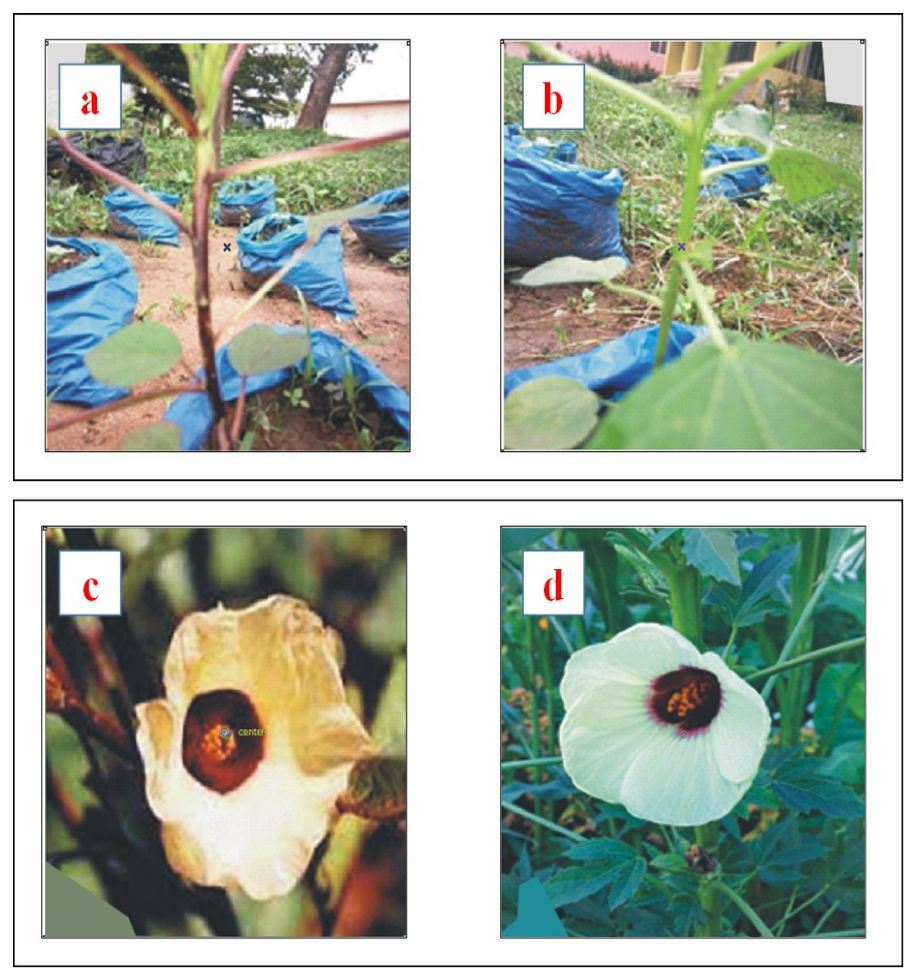

Figure 2. a): stem of red variety; b): stem of green variety; c): flower of red variety; $d$ ): flower of green variety.

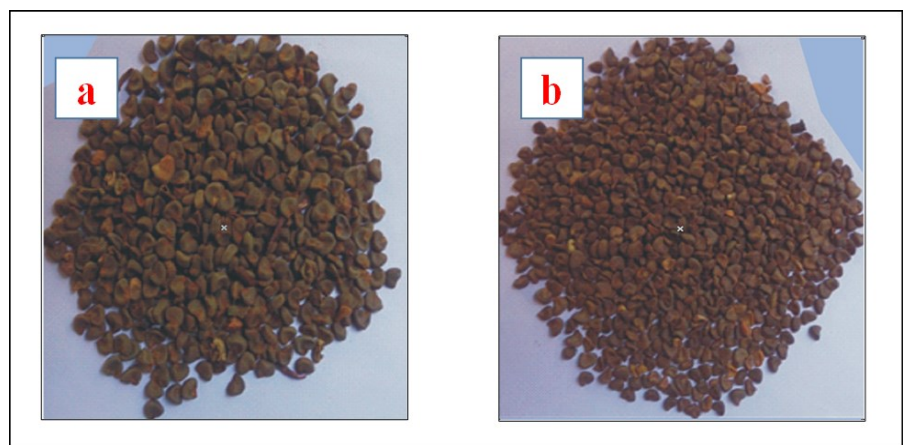

Figure 3. a): seeds of red variety; b): seeds of green variety.

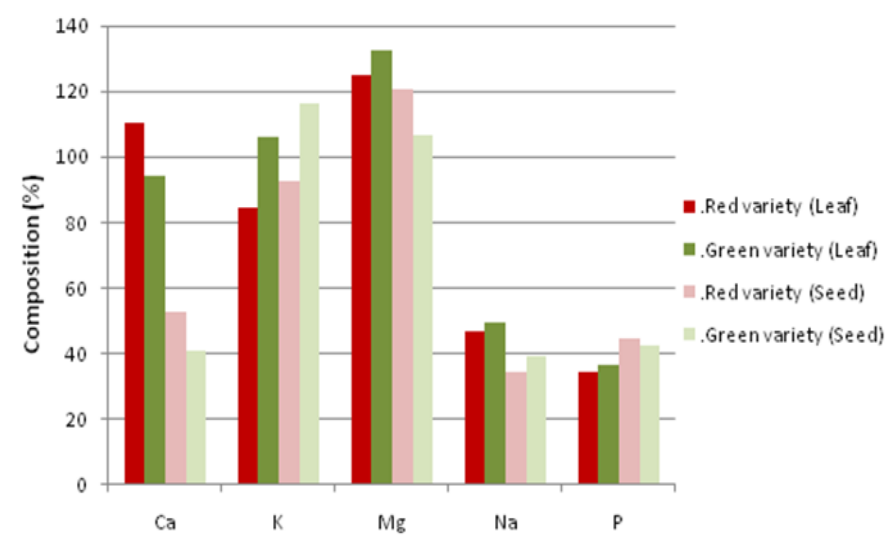

Figure 4. Percentage mineral composition of the leaf and seed of red and green varieties of Hibiscus sabdariffa.

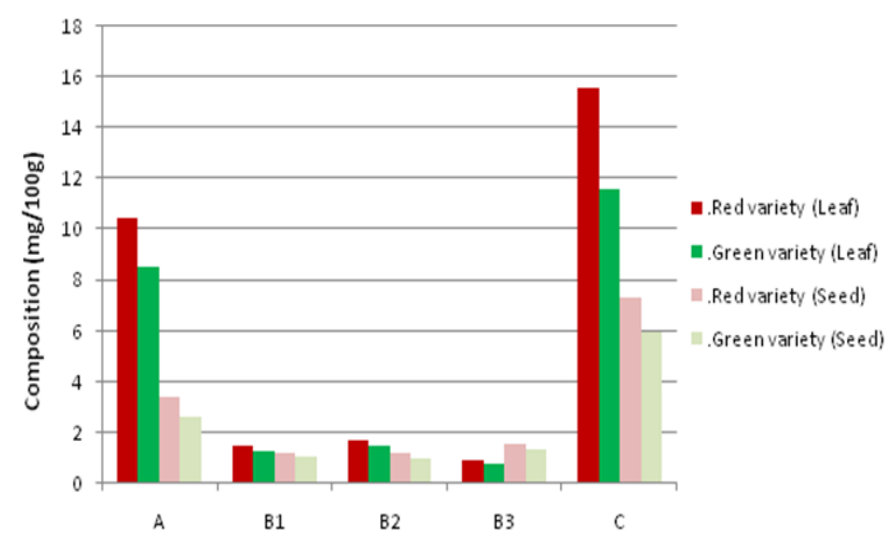

Figure 5. Vitamin composition of the leaf and seed of red and green varieties of Hibiscus sabdariffa.

Conclusion

The results of the study revealed that these parts of the two varieties investigated are nutritious and can contribute significantly to the human health requirements thus could be extracted for the manufacture of food and drugs supplements. Overall data could be used as a viable tool in Roselle breeding for improvement in Roselle production and also to enhance proper taxonomic characterization and identification of the plant species which have immense economic potentials as ornamental plants.

\section{Author's contributions}

This work was carried out in collaboration between all authors. Author CVI designed the study and author El wrote the protocol. All Authors wrote the first draft of the manuscript. All Authors managed the analyses of the study and the literature searches. All authors read and approved the final manuscript.

\section{Competing interests}

Authors have declared that no competing interests exist.

Open Access: This is an open access article distributed under the terms of the Creative Commons Attribution 4.0 License, which permits unrestricted use, distribution, and reproduction in any medium, provided the original author(s) if the sources are credited. 


\section{REFERENCES}

Abdallah, E.M. (2016). Antibacterial activity of Hibiscus sabdariffa L. calyces against hospital isolates of multidrug resistant Acinetobacter baumannii. Journal of Acute Disease, 5(6): 512-516.

Adanlawo, I.G. and Ajibade, V.A. (2006). Nutritive value of the two varieties of Roselle (Hibiscus sabdariffa) calyces soaked with wood ash. Pakistan Journal of Nutrition 5(6): 555-567.

Adewale, B.D., Okonji, C., Oyekanmi, A.A., Akintobi, D.A.C. and Aremu, C.O. (2010). Genotypic variability and stability of some grain yield components of cowpea. African Journal of Agricultural Resource, 5: 874-880.

Alegbejo, M.D. (2000). Processing, utilization and nutritional value of Okra and Roselle. Noma Magazine, 14: 43-45.

Ali, B.H., Al Wabel, N. and Blunden, G. (2005). Phytochemical, pharmacological and toxicological aspects of Hibiscus sabdariffa L. Phytotherapy Research, 19: 369-375.

AOAC, (2005). Official Method of Analytical Chemistry, Washington DC, pp. 235.

Aremu, C.O., Ariyo, O.J. and Adewale, B.D. (2007). Assessment of selection techniques in genotype $X$ environment interaction in cowpea Vigna unguiculata (L.) Walp. African Journal of Agricultural Resource, 2: 352-355.

Aziagba, B.O., Okeke, C.U., Ezeabara, C.A., Ilodibia, C.V. and Obika, I.E. (2016).Taxonomic Implication of Morphology of Seven Varieties of Vigna unguiculata (L.) Walp. Cultivated in Awka, Anambra State, South Eastern Nigeria. America Journal of Life Science Researches, 4(4): 132-137

Babalola, S.O. (2000). Chemical analysis of roselle leaf (Hibiscus sabdariffa), in proceedings of $24^{\text {th }}$ annual conference of NIFST; pp. 228-229.

Cisse, M., Domier, M., Sakho, M., N'Diaye, A., Reynes, M. and Sock, O. (2009). Le bissap (Hibiscus sabdariffa L): Composition etprincipales utilizations. Fruits, 64(3): 179-185.

Da-Costa-Rocha, I., Bonnlaender, B., Sievers, H., Pischel, I., \& Heinrich, M. (2014). Hibiscus sabdariffa L.-A phytochemical and pharmacological review. Food chemistry, 165, 424-443.

Daudu, O.A.Y., Falusi, O. A., Dangana, M.C., Abubakar, A., Yahaya, S. A. and Abejide, D.R. (2015). Collection and evaluation of Roselle (Hibiscus sabdariffa L.) germplasm in Nigeria. African Journal of Food Science, 9(3): 92-96.

Davey, M.W., Montagu, M.U., Inze, D., Sanmartin, M., Kanellis, A., Smirnoff, N., Benzie, I.F., Strain, J.J., Favell, D. and Fletcher, J. (2000). Plant Ascorbic Acid: Chemistry, Function, Metabolism, Bioavailability And Effects Of Processing. Journal on Food Agriculture, 80: 825-860

El Hakim, A.E. (2010). Biochemical and molecular characterization of three colored types of roselle (Hibiscus sabdariffa L.). Journal of American Science, 6(11); 726-733.

Essa, M.M., Subramanian, P., Suthakar, G., Manivasagam, T., Dakshayani, K.B., Sivaperumal, R., Subash, S. and Vinothini, G. (2006). Influence of Hibiscus sabdariffa (Gongura) on the levels of circulatory lipid peroxidation products and liver marker enzymes in experimental hyperammonemia. Journal of Applied Biomedicine, 4: 53-58.

Gautam, R.D. (2004). Sorrel- A lesser-known source of medicinal soft drink and food in India. Natural Product Radiance, 3(5): 338-342.

Haji, F.M. and Haji, T.A. (1999). Production and quality evaluation of wine produced from zobo extract (Hibiscus sabdariffa) and the effect of the extract on hypertensive wester rats. Nigeria Food Science Technology, 12:26-27.

Haji-Faraji, M. and Haji-Tarkhani, A. (1999). The effect of sour tea (Hibiscus sabdariffa) on essential hypertension. Journal of Ethnopharmacology, 65: 231-236.

Herrera-Arellano, A., Flores-Romero, S., Chavez-Soto, M.A. and Tortoriello, J. (2004). Effectiveness and tolerability of a standardized extract from Hibiscus sabdariffa in patients with mild to moderate hypertension: a control and randomized clinical trial. Phytomedicine, 11: 375-382.

Ilodibia, C.V., Achebe, U.A. and Chiafor, C. (2017). Nutrient characteristics assessment of two variants of okra (Abelmoschus esculentus L. Moench.) found in Anambra State, Nigeria. Archives of Agriculture and Environmental Science, 2 (4): 298-300

Ilodibia, C.V., Chukwuka, C., Chukwuma, M.U., Akachukwu, E.E., Igboabuchi, N.A. and Adimonyemma, R.N. (2016b). Proximate composition, vitamin and anatomical studies on Celosia argentea. British Biotechnology Journal, 15(4): 1-7.

Ilodibia, C.V., Eze, E., Chukwuma, M.U., Akachukwu, E.E., Igboabuchi, N.A. and Adimonyemma, R.N. (2016a). Proximate, vitamin, mineral and anatomical studies on Vitex chrysocarpa Planch ex Benth. (Verbenaceae). Journal of Advances in biology and biotechnology, 9(1): 1-5.

Ismail, A., Ikram, E.H.K. and Nazri, H.S.M. (2008). Roselle (Hibiscus sabdariffa L.) seeds nutritional composition protein quality and health benefits. Food, 2(1): 1-16.

James, C.S. (1995). Analytical Chemistry of Foods. Chapman and Hall, New York. 178pp.

Judd, W.S., Campbell, C.S., Kellogg, E.A., Stevens, P.F. and Donoghue, M.J. (2008). Plant Systematics: A Phylogenetic Approach, $3^{\text {rd }}$ edition. Sinauer Associates, Inc. Sunderland, U.S.A. pp. 565.

Konan, A.G., Konan, Y. and Kone, M.W. (2015). Polyphenols content and antioxidant capacity of traditional juices consumed in Côte d'Ivoire. Journal of Applied Biosciences, 87: 8015-8021.

Lawton, B.P. (2004). Hibiscus: Hardy and Tropical Plants for the Garden. Timber press, Portland, U.S.A. pp. 36.

Mahadevan, N., Shivali, O.E and Kamboj, P. (2009). Hibiscus sabdariffa Linn. An overview. Natural Product Radiance, 8: 77-83.

Mohamed, R., Fernadez, J., Pineda, M. and Aguilar M. (2007). Roselle (Hibiscus sabdariffa) seed oil is a rich source of Y-tocopherol. Journal of Food Science, 72: 207-211.

Mohamed, B.B., Sulaiman, A.A. and Dahab, A.A. (2012). Roselle (Hibiscus sabdariffa L.) in Sudan, cultivation and their uses. Bull. Environ. Pharmacol. Life Sci, 1(6): 48-54.

Mokhtari, Z., Zarringhalami, S. and Ganjloo, A. (2018). Evaluation 
of Chemical, Nutritional and Antioxidant Characteristics of Roselle (Hibiscus sabdariffa L.) Seed. Nutrition and Food Sciences Research, 5(1): 41-46

Morton, J. (1987). Roselle. In: Julia, F. (ed). Fruits of Warm Climates. FL, Miami. pp. 281-286.

Mukherjee, A., Banerjee, K. and Dutta, A.K. (2017). Review on amaging benefits of roselle (Hibiscus sabdariffa L.) and their uses". World Journal of Pharmacy and Pharmaceutical Sciences, 6(7): 217-227.

Mwasiagi, J.I., Yu, C.W., Phologolo, T., Waithaka, A., Kamalha, E., and Ochola, J.R. (2014). Characterization of the Kenyan Hibiscus sabdariffa L. (Roselle) Bast Fibre. Fibres \& Textiles in Eastern Europe

Obouayeba, A.P., Djyh, N.B., Diabate, S., Djaman, A.J., N'guessan, J.D., Kone, M. and Kouakou, T.H. (2014). Phytochemical and antioxidant activity of roselle (Hibiscus sabdariffa L.) petal extracts. Research Journal of Pharmaceutical, Biological and
Chemical Sciences, 5(2): 1453-1465.

Ochani, P.C. and D'Mello, P. (2009). Antioxidant and antihyperlipidemic activity of Hibiscus sabdariffa Linn. leaves and calyces extracts in rats.

Odigie, I.P., Ettarh, R.R. and Adigun, S. (2003). Chronic administration of aqueous extract of Hibiscus sabdariffa attenuates hypertension and reverses cardiac hypertrophy in $2 \mathrm{~K}-1 \mathrm{C}$ hypertensive rats. Journal of Ethnopharmacology, 86: 181-185.

Singh, P., Khan, M. and Hailemariam, H. (2017). Nutritional and Health Importance of Hibiscus Sabdariffa: A Review and Indication for Research Needs. Journal of Nutritional Health and Food Engineering, 6(5), 1-4.

Taylor, D.J. Green, N.P.O. and Stout, G.W. (2005). Biological Science, $3^{\text {rd }}$ edition. Cambridge University Press, UK. pp. 218.

Tsai, J. and Ou, M. (1996). Colour degradation of dried Roselle during storage. Food Science, 23: 629-640. 